\title{
Prospecting genes associated with navel length, coat and scrotal circumference traits in Canchim cattle
}

\author{
Andrea Renata da Silva Romero ${ }^{\mathrm{a}}$, Fabiane Siqueira ${ }^{\mathrm{b}, *}$, Gustavo Garcia Santiago ${ }^{\mathrm{c}}$, \\ Luciana Correia de Almeida Regitano ${ }^{\mathrm{d}}$, Maury Dorta de Souza Júnior ${ }^{\mathrm{e}}$, \\ Roberto Augusto de Almeida Torres Júnior ${ }^{\mathrm{b}}$, André Vieira do Nascimentof, \\ Alexeia Barufatti Grisolia ${ }^{a}$
}

${ }^{\text {a }}$ Federal University of Dourados (UFGD), Dourados, Mato Grosso do Sul, Brazil

${ }^{\mathrm{b}}$ Embrapa Beef Cattle, Campo Grande, Mato Grosso do Sul, Brazil

${ }^{\mathrm{c}}$ Federal University of Mato Grosso do Sul (UFMS), Campo Grande, Mato Grosso do Sul, Brazil

${ }^{\mathrm{d}}$ Embrapa Southeast Livestock, São Carlos, São Paulo, Brazil

e Brazilian Association of Canchim Cattle Breeders (ABCCAN), Água Branca, São Paulo, Brazil

${ }^{\mathrm{f}}$ São Paulo State University (UNESP), Jaboticabal, São Paulo, Brazil

\section{A R T I C L E I N F O}

\section{Keywords:}

Inference Bayesian

GWAS

Polymorphisms

SNP

\begin{abstract}
A B S T R A C T
The aim of this work was to identify genomic regions and genes in association with the navel length, coat and scrotal circumference traits of Canchim breed of cattle, using genome-wide association studies (GWAS). Imputed data from single nucleotide polymorphism type markers were used, with accuracy greater than 95\%. The analyses of genome-wide association were conducted by the Bayes B method, implemented in the GenSel program. Non-overlapping windows that explained at least $0.19 \%$ of the additive genetic variance were considered as significant, this value corresponds five times the expected for $1 \mathrm{Mb}$ size windows. GWAS indicated 31 regions in association with navel length, one coat region, and four SC-related regions. In these regions, 4 quantitative loci (QTLs) related to navel length and 5 with SC were identified, as for the coat, the QTLs detected did not present previously described relation with this trait. Among the candidate genes in the associated regions, 7 genes were cited in previous studies, with biological functions related to navel length, one for coat and three for SC. The candidate genes TMEM176A and TMEM176AB, which are orthologous in humans, are in association with navel's trait and compose the Androgen Induced 1 cluster. The identification of genes and QTLs, with a function related to the studied traits, previously described in the literature, reinforces the evidence that the found regions are associated with navel length, coat and SC. This information may contribute to the understanding of the genetic architecture involved with of these traits, to guiding genetic validation studies, gene introgression and contribute to include information concerning molecular markers in genetic evaluation of animal improvement programs.
\end{abstract}

\section{Introduction}

Canchim bulls (5/8 Charolais and 3/8 Zebu), introduced into mating systems for increased meat production, might provide an additional in carcass weight upon slaughter, compared to other beef cattle breeds (Tupy et al., 2006). The Canchim breed also has excellent meat quality, and is well suited to the tropical environmental conditions (Buzanskas et al., 2014; Mokry et al., 2013). Quantitative genetic research has already been conducted on this breed to evaluate the genetic parameters associated with the economically important phenotypic traits, like reproductive performance, navel length and coat. However, the specific chromosomal regions or genes responsible for the variations of these traits still need to be analyzed (Barichello et al., 2010; Bignardi et al., 2011; Buzanskas et al., 2014).

Genome-wide association studies (GWAS) have been used in beef cattle to evaluate markers of single nucleotide polymorphisms (SNP), which are associated with the manifestation of quantitative characters. The information obtained from these markers explain the phenotypic

\footnotetext{
* Corresponding author.

E-mail addresses: andrearomerofma@gmail.com (A.R. da Silva Romero), fabiane.siqueira@embrapa.br (F. Siqueira), gustavo_garciasantiago@hotmail.com (G.G. Santiago), luciana.regitano@embrapa.br (L.C. de Almeida Regitano), maurydorta@yahoo.com.br (M.D. de Souza Júnior), roberto.torres@embrapa.br (R.A. de Almeida Torres Júnior), andrevn16@gmail.com (A.V. do Nascimento), alexeiagrisolia@ufgd.edu.br (A.B. Grisolia).
} 
variations partly, thereby improving the accuracy of animal selection for directed mating, resulting in an increased genetic gain under a higher selection pressure (Cantor et al., 2010; Santana et al., 2014).

Phenotypes associated with adaptation and functionality, such as coat and navel length are among the traits of interest for herd improvement. Animals with a navel surpassing the hock line are more susceptible to foreskin prolapse and pathologies, due to increased contact with grass. Therefore, it is suitable to eliminate animals with such navel traits from productive establishments. Coat traits are linked to the breed and aspects of adaptation. For instance, cattle with short and clear hair are preferable for husbandry in tropical regions. It is important that both these phenotypes, viz, navel length and coat traits, be considered while selecting livestock breeds for particular environments (Ortega et al., 2007; Windeyer et al., 2014).

Scrotal circumference (SC) is directly related to the reproductive performance in bulls and sexual precocity in their female progeny, and thus is another character that economically affects the breeding of beef cattle (Fordyce et al., 2014; Utsunomiya et al., 2014).

The objective of this study was to detect chromosomal regions and genes associated with the navel length, coat and scrotal circumference traits of Canchim breed of cattle, using the Bayesian methods applied to GWAS. The results of this study may to contribute to the genetic improvement of the Canchim breed.

\section{Material and methods}

\subsection{Deregressing estimated breeding values}

Deregressed estimated breeding values (dEBV) of 1106 animals were used to evaluate navel length, coat and SC traits, following the methodology proposed by Garrick et al. (2009). The dEBVs were corrected to the animal age effect (linear and quadratic as covariates) and contemporary groups formed by the combination of year of birth, birth season, herd, gender and genetic group. This information was obtained from the database of the Embrapa-Geneplus Genetic Improvement Program for the Canchim breed of cattle.

\subsection{Genotyping data}

To genotype the animals, blood samples were collected in $4.5 \mathrm{~mL}$ Vacutainer ${ }^{\circledR}$ tubes with K3-EDTA, and were then processed to obtain leucocytes. Semen samples were obtained from the bulls, which genetic evaluation tests showed to have representative calves. DNA was extracted following the method described by Regitano and Coutinho (2001). The samples were genotyped by Illumina technology service providers.

The genotypic data of the studied animals came from the Embrapa Beef Cattle (EBC) and Embrapa Southeast Livestock (ESL) databases. The first of the three datasets from EBC included data from 462 individuals, which were genotyped using the Illumina BovineSNP50 v2 BeadChip $^{\circledR}(50 \mathrm{~K})$. The second dataset, consisting of data from 169 individuals, was genotyped using the GeneSeek Genomic Profiler $H D^{\circledR}$ (80k), and the third dataset, consisting of data from 13 individuals, was genotyped using the BovineHD BeadChip ${ }^{\circledast}$ (HD). A total of 548 of the 644 individuals genotyped, were from the Canchim breed, and 96 were from the genetic group MA (Charolais bull progeny derived from mating with $1 / 2$ Canchim $+1 / 2$ Zebu dams; on average $65.6 \%$ Charolaise and $34.4 \%$ Zebu).

All genotypes in the EBC database belong to animals that participated in the Canchim Performance Evaluation Tests (CPET) carried out between 2011 and 2014 by the Brazilian Association of Canchim Breeders (ABCCAN) and the Geneplus/Embrapa Program.

Information from the ESL genomic database on 57 animals, offspring of 49 bulls, presenting a calculated Estimated Progeny Difference (EPD), was used. These animals were genotyped on the BovineHD BeadChip $^{\circledast}$ (HD) platform, and included 30 females (21 Canchim and 9
MA) and 27 males (11 Canchim and 16 MA).

\subsection{Quality control and imputation}

Only single nucleotide polymorphisms (SNP) with known genomic coordinates from autosomal chromosomes were considered as quality controls for the genomic data. At this stage, each data set was analyzed separately. The following exclusion criteria and thresholds were used: genotypes with Genotype Calling Scores below 50\%, samples and SNPs with call rates below 95\%, minimum allele frequency (MAF) of $5 \%$ of samples with heterozygosis $>75 \%$, and the P-value for the chi-square test for Hardy-Weinberg equilibrium $<0.000001$. Additionally, the SNPs located in the same genomic coordinates with the lowest MAF and the SNP pairs with correlation values above 0.98 and lowest MAF were excluded. The defined exclusion criteria and thresholds were applied using scripts in the statistical software R v.3.1.3 (R Development Core Team, 2013), using the package snpStats v1.16.0 (Clayton, 2012).

Imputation was performed using the FImpute software v.2.2. (Sargolzaei et al., 2014), following the method described by Santiago et al. (2017). After imputation, the genomic data underwent a new quality control check and only the markers with accuracy above $95 \%$, MAF above $5 \%$ and P-value $<0.000001$ for the chi-square test for Hardy-Weinberg equilibrium were retained for further analyses. SNPs with lower MAF values among the highly correlated pairs of SNPs ( $>0.98$ ) were also excluded.

\subsection{Genome Wide Association Study (GWAS)}

GWAS was conducted on the Linux operating system, using the Bayes $B$ method from the GenSel v.1.14 software (Fernando and Garrick, 2008), which uses a Monte Carlo simulation via Markov chains to estimate the effect of the markers.

The genotypes and the dEBV data were simultaneously analyzed, and only the animals for which both the information was available were used in the study. Thus, 697 animals (each with genotype and dEBV information) remained after quality control checks, and were analyzed for navel length, coat and SC traits.

The Markov chains included 50,000 iterations, of which the first 10,000 were discarded in the burn-in. Estimates of marker effects were sampled after every four iterations. Therefore, the a posteriori distribution of the marker effects was inferred from 10,000 of total iterations. The value of $\pi$ (proportion of the markers to have a zero effect) used a priori in Bayes $B$ was obtained through the Bayes $C \pi$ methodology, using the a priori values of 0.5 (Habier et al., 2011). The model used was described by Kizilkaya et al. (2010):

$\boldsymbol{y}_{j i}=\sum_{i=1}^{k} \boldsymbol{z}_{i} \boldsymbol{a}_{i} \delta_{i}+\boldsymbol{e}_{j i}$

Where $y$ is a vector of dEBVs; $k$ is the total number of markers; $z_{i}$ is the vector of genotypes of the fitted $S N P_{i}$, coded $-10,0$ and 10 (codification required by the GenSel software) for genotypes $\mathrm{AA}, \mathrm{AB}$ and $\mathrm{BB}$, respectively; $a_{\mathrm{i}}$ is the vector of allelic substitution for $S N P_{i}$ assumed a zero effect with probability $\pi$ or a non-zero effect with probability $1-\pi$; $\delta_{i}$ indicates if $S N P i$ is included in $\left(\delta_{i}=1\right)$ or excluded $\left(\delta_{i}=0\right)$ from the analyses; and $e$ is the vector of residuals effects of animals $j i$.

Windows with multiple markers capture a large part of the variance within the chromosomal regions (Saatchi et al., 2012). Therefore, genes and genomic regions that are candidate associated with length navel, coat and SC were identified using windows of size $1 \mathrm{Mb}$ (1 million base pairs) non-overlapping (2521 windows) assuming an equal contribution for genetic variance (Schurink et al., 2012). The effect of the variance explained by each window was estimated using the GenSel software.

The proportion of the estimated additive genetic variance expected for a specific window was calculated according to Onteru et al. (2013), where $100 \%$ / 2521 resulted in $0.039 \%$. Thus, windows that explained at least $0.19 \%$ of the genetic variance, which is five times higher than 
expected $(0.039 \% * 5=0.19 \%)$, were considered as regions associated with the quantitative trait loci (QTLs). The effect of the markers was standardized according to suggested by Sollero et al. (2014).

\subsection{Functional enrichment}

The significant windows detected by GWAS were assessed using the CattleQTLdb database (Hu et al., 2006) to recognize loci affecting previously described quantitative traits in cattle. These regions were also looked up in the BioMart tool (Ensembl Release 89) (Kinsella et al., 2011) using the annotation of the bovine genome UMD3.1 to find out the candidate genes. Available literature was searched to find out the previously described associations between the studied characteristics and the genes detected by GWAS.

The detected genes were subjected to a functional analysis, using the software DAVID Bioinformatics Resources 6.8 (Dennis et al., 2003) with the objective of classifying the genes into functional categories. Information on the orthologous genes of humans was also included in this search, due to the superior genome annotation ability of human genome.

\section{Results}

GWAS pointed out 31 regions associated with navel length, one region associated with coat and four regions associated with SC traits (Supplementary Fig. S1). Due to the high number of regions identified by the genomic analysis for navel length only the 10 most significant regions were used in the functional analysis (Supplementary Material, Table S1).

The search for QTLs in the CattleQTLdb database showed 111 QTLs 68 for navel length, 4 for coat and 39 for SC traits (available in the Supplementary Material, Table S2). Out of the 111 QTLs identified, the QTLs whose association with the studied characteristics has been described by previous researches are listed in Table 1 .

The most promising genomic regions associated with navel length were located on chromosome 5. No specific loci for navel length were identified in the CattleQTLdb database, but QTLs for correlated traits, namely, coat coloration and reproductive traits, were identified. The QTLs identified for SC trait were associated with reproduction in males and females. In addition, QTLs unrelated to pelage characteristics, but related to milk production, body size and shear force were detected in the windows associated with coat characteristics.

Upon referring the Ensembl database to identify significant regions, 88 genes associated with navel length, two with coat, and 37 with SC traits were identified (Supplementary Material, Table S3). These candidate genes were searched for in the available literature. References of eleven genes were found in connection with biological functions related to the selected traits; seven for navel length, one for coat and three for SC traits. These genes are listed in Table 2.

The genes TMEM176A and TMEM176B are likely candidates for

Table 1

Accession number of quantitative traits loci positioned in chromosome regions that showed association with length navel and scrotal circumference, and then have any relationship described by previous researches with the traits studied.

\begin{tabular}{lllll}
\hline Traits & QTLs $^{\mathrm{a}}$ & BTA $^{\mathrm{b}}$ & Accession number $^{\mathrm{c}}$ \\
\hline \multirow{2}{*}{ Navel } & Coat coloring & 5 & 37341 & \\
& Fertility rate & 5 & 62357 & \\
\multirow{2}{*}{ Scrotal Circumference } & Daughter pregnancy rate & 8 & 43818 & \\
& Calving ease & 8 & 43825 & \multirow{2}{*}{15276} \\
& Inseminations per & 12 & & \multirow{2}{*}{65823} \\
& conception & & & \\
& sperm counts & 1 & & \\
\end{tabular}

\footnotetext{
${ }^{a}$ Quantitative trait loci.

b Bovine Chromosome.

c Accession number at the Cattle QTLdb.
}

association with navel length, are orthologous in humans, and constitute the Androgen Induced 1 cluster (AIG1, Id: GO:0005525). No relationships were identified between the candidate genes and the clusters for coat and SC traits.

\section{Discussion}

The fertility-rate related QTL, present in one of the regions associated with the navel length phenotype, is associated with bovine reproduction, corroborating findings that highlight the importance of navel length for reproductive aspects in bulls (Windeyer et al., 2014). This is due to the hereditary factors that predispose animals with elongated and pendulous navels to experience preputial prolapse (Koury Filho et al., 2003).

The prepuce is a part of the external genitalia of bulls, is composed externally of skin and internally of muscles, preputial cavities and secretory glands. The prepuce becomes susceptible to diseases when it is elongated, thereby hindering or disabling intercourse and causing loss of libido in the animals. These problems lead to low reproductive efficiency of the herd and to economic losses (Koury Filho et al., 2003; Rabelo et al., 2012).

Based on the previously established relationship between lengths of the navel and prepuce the NOS3 gene, considered a likely candidate for association with navel traits, was identified in the dermal microvascular endothelial cells of the neonatal prepuce. These cells are involved in various physiological and pathological processes of the skin, among which are the activities linked with immunity, tissue aging and angiogenesis during healing (Cha et al., 2005; McGowan et al., 2002).

Problems created by elongated navels affect mostly bulls, since they are more susceptible to diseases caused by contact of the navel with the grass. In addition, elongated navels, because of their connection with the prepuce, may alter the reproductive performances of the bulls. However, the high correlation between the navel phenotype in bulls and dams (0.80) suggests that selecting for navel lengths in heifers affects the navel lengths of bulls (Koury Filho et al., 2003).

The genes IGSF5 and DDX25, in chromosomal regions associated with navel length, were also related to reproductive aspects. Gene expression studies using rats identified the gene IGSF5 as being associated with infertility. It is expressed in the mesonephron and is necessary for the formation of the sperm producing seminiferous tubules in the testes (Gitton et al., 2002).

The gene DDX25 is present in the testicular cells of rodents and its expression is essential for the fertility of mice. However, the metabolic pathways involved in the expression of this gene remain largely unexplored (Tsai-Morris et al., 2007).

Navel length and coat are important physical traits influencing the adaptation of cattle to the temperate climate and prevailing pasture regime in Brazil. Therefore, knowledge of the common genomic regions that affect the expression of these phenotypes can be used to improve both traits simultaneously (Corbet et al., 2007). GWAS detected a QTL on chromosome 5 which is related to the coat phenotype. Porto-Neto et al. (2014) reported in the Brahman breed of cattle close association between the two characters, navel length and coat, both coded for genes located on chromosome 5 .

The gene WIFI, likely associated with the traits of the navel, was detected in the expression analysis and is related with the amount of fur in rats. This gene is present in BTA 5 and interacts with bone morphogenetic proteins involved in forming and determining the size of hair follicles (Sharov et al., 2006).

The genes TMEM176A and TMEM176B are expressed in cells associated with the immune system. Defects in the transcription of these genes increase the incidences of skin inflammation, such as psoriasis, in humans (Drujont et al., 2016).

The expression of the PKIB gene detected in genome-wide association studies in bovines, has been related to the aspects of adaptation in tropical regions, since it was not identified in individuals from any 
Table 2

Candidate genes with biological functions associated with the traits studied.

\begin{tabular}{|c|c|c|c|c|}
\hline Gene & Phenotype & Chromosome & Function & Gene name \\
\hline IGSF5 & Navel & 1 & Reproduction & immunoglobulin superfamily member 5 \\
\hline NOS3 & Navel & 4 & Foreskin & nitric oxide synthase 3 \\
\hline TMEM176A & Navel & 4 & Skin & transmembrane protein $176 \mathrm{~A}$ \\
\hline TMEM176B & Navel & 4 & Skin & transmembrane protein $176 \mathrm{~B}$ \\
\hline WIF1 & Navel & 5 & coat & WNT inhibitory factor 1 \\
\hline PKIB & Navel & 9 & Adaptation & Proteína kinase \\
\hline DDX25 & Navel & 29 & Reproduction & DEAD-box helicase 25 \\
\hline NTNG1 & Coat & 3 & Coat & Netrin G1 \\
\hline BRCA2 & SC & 12 & Reproduction & DNA repair associated \\
\hline LOXL1 & SC & 21 & Reproduction & lysyl oxidase like 1 \\
\hline GZMB & SC & 21 & Reproduction & granzyme B \\
\hline
\end{tabular}

other region. This difference in expression was attributed to the regional differences in selective pressures influencing mammalian survival (Amorim et al., 2015; Chung et al., 2009).

Available literature did not report any corresponding quantitative loci for the region that was pointed out by GWAS to be associated with coat traits. However, this region may be considered for QTL analysis to detect the presence of the NTNG1 gene, which has been associated with coat traits in this and other studies; there is, therefore, a need to carry out further studies on this region. The candidate gene NTNG1 was confirmed as differentially important for influencing the smoothness or curliness of sheep's coat (Kang et al., 2013). Coat morphology is important for the adaptation of the animal to the environment, because it affects heat exchange between the body and the environment by influencing thermal insulation, efficiency of evaporative thermolysis (thermoregulation that ensures heat loss in the animals) and associated thermoregulatory characteristics. The size and number of the sweat glands are among the thermoregulatory attributes associated with coat and are of particular importance in warm environments for short and smooth haired animals (Barnabe, 1975; Li et al., 2014; Nicolau et al., 2004).

Bovine coat traits are related to the incidences of tick infestations, since animals that undergo either heat- or cold-stress, have a reduced resistance caused by the release of adrenocorticotrophic hormone (ACTH). It is important to highlight that ACTH also triggers reactions that alter or inhibit the secretion of gonadotrophic hormones, causing infertility or low reproductive efficiency (Tsuma et al., 1997).

The QTLs and genes that influence the pregnancy rate in the female progeny ease of delivery and chances of conception following insemination were detected in the regions likely associated with the SC traits. These results corroborate the findings from previous studies that establish the relationship between SC characteristics and reproductive traits in females. The correlation between the SC traits and the amount of sperm produced further establishes the association of these characteristics with the reproductive capacity of bulls, thereby corroborating the results obtained in this study (Silva et al., 2001).

There are controversies in the selection of heifers through the results obtained by breeding on bulls. However, correlation studies between scrotal circumference and reproductive traits in offspring provided satisfactory estimates. These results show the possibility of considering SC traits as an indicator of desirable reproductive traits in females (daughters). For example, the age of puberty showed a correlation of -0.70 with SC characteristics. This negative correlation is desirable; it indicates that the bigger the SC of the bulls, the lower will be the age at which their daughters will enter puberty (Santana et al., 2014).

$B R C A 2$ is one of the genes present in the regions pointed out by GWAS for possible association with SC traits and mutations in this gene are connected with the development of breast, ovary and prostate cancers in humans (Fortuny et al., 2008).

The gene LOXL1 encodes a protein involved in the formation of elastic fibers, and is important to understand mechanisms related to pelvic organ prolapse. Mutations in this gene cause vaginal descent and prolapse of the uterus, bladder and rectum by lowering the pelvic floor musculature in rats and primates (Consonni et al., 2012). In bulls, mutations in this gene were found to be associated with decreased testicular protrusion (including perineal protrusion), under-developed scrotal morphology, reduced anogenital distance, poorly palpable or nonpalpable testicles and reduced sperm concentration. Previous researchers have linked the gene LOXL1 to fertility in rats (Wood et al., 2009).

The candidate gene GZMB is associated with successful pregnancy in rats. Changes in this gene have been reported to cause low fertility by making implantation of the embryo in the uterus difficult (Nuño-Ayala et al., 2012). The expression of the GZMB gene was also detected in the equine endometrium and its importance in establishing pregnancy was recognized (Tachibana et al., 2013).

The relationships between the candidate genes (associated with navel length, coat and SC traits) in the gene networks and the gene clusters were investigated. For this search, were used orthologous genes mapped in humans. Human genome information was used because humans are the only mammalian species with the best annotated genome (Monaco et al., 2015).

The genes TMEM176A and TMEM176B are likely candidates for association with navel length traits, are orthologous in humans and constitute the Androgen Induced 1 cluster (AIG1, Id: GO:0005525). Genes belonging to this cluster have been related with prostate cancer because of their important role in regulating apoptosis and maintaining the cell cycle (Levina et al., 2015). The absence of any detected relationship between the genes identified for coat- and SC traits with the gene clusters is probably because these genes act independently.

\section{Conclusions}

Loci and candidate genes previously described in the literature were detected in this study through GWAS analyses, with a function related to the studied traits. It contributes to reinforcing the signs of association with length navel, coat and scrotal circumference. This knowledge may contribute to the understanding of the genetic architecture involved in the expression of these traits.

Furthermore, our results can act to collaborating to direct future genetic validation studies, gene introgression and contribute to include information concerning molecular markers in genetic evaluation of animal improvement programs.

\section{Acknowledgements}

The authors would like to thank Coordination for the Improvement of Higher Education Personnel (CAPES) for their financial support; the Brazilian Corporation of Agricultural Research (EMBRAPA) for making available the genotype date and the producers of the Brazilian Association of Breeders of the Canchim Breed (ABCCAN) for having ceded biological samples of the animals analyzed and to the breeding program Geneplus/Embrapa for making available DEPs of the animals. 


\section{Funding}

This work was financed by the Brazilian Agricultural Research Corporation (EMBRAPA).

\section{Ethics statement}

For the current study, data were collected in accordance with the Embrapa Southeast Livestock and the Embrapa Beef Cattle Ethical Committee of Animal Use under protocols numbers 02/2009 and 10/ 2015, respectively.

\section{Competing interests}

The authors declare that they have no competing interests.

\section{Conflict of interest statement}

None of the authors of the manuscript entitled have potential conflicts of interest which should be disclosed.

\section{Appendix A. Supplementary material}

Supplementary data associated with this article can be found in the online version at http://dx.doi.org/10.1016/j.livsci.2018.02.004.

\section{References}

Amorim, C.E.G., Daub, J.T., Salzano, F.M., Foll, M., Excoffier, L., 2015. Detection of convergent genome-wide signals of adaptation to tropical forests in humans. PloS ONE 10, e0121557.

Barichello, F., Alencar, M.Md, Torres Júnior, R.Ad.A., Silva, L.O.Cd, 2010. Herdabilidade e correlações quanto a peso, perímetro escrotal e escores visuais à desmama, em bovinos Canchim. Pesqui. Agropec. Bras. 563-570.

Barnabe, R.C., 1975. Variações estacionais no pelame de vacas da raça Jersey e sua correlação com a produção leiteira. Braz. J. Vet. Res. Anim. Sci. 12, 95-106.

Bignardi, A., El Faro, L., Torres Júnior, R., Cardoso, V., Machado, P., Albuquerque, L.Gd, 2011. Random regression models using different functions to model test-day milk yield of Brazilian Holstein cows. Genet. Mol. Res. 3565-3575.

Buzanskas, M.E., Grossi, D.A., Ventura, R.V., Schenkel, F.S., Sargolzaei, M., Meirelles, S.L., Mokry, F.B., Higa, R.H., Mudadu, M.A., da Silva, M.V.B., 2014. Genome-wide association for growth traits in canchim beef cattle. PloS ONE 9, e94802.

Cantor, R.M., Lange, K., Sinsheimer, J.S., 2010. Prioritizing GWAS results: a review of statistical methods and recommendations for their application. A. J. Hum. Genet. 86, 6-22.

Cha, S.T., Talavera, D., Demir, E., Nath, A.K., Sierra-Honigmann, M.R., 2005. A method of isolation and culture of microvascular endothelial cells from mouse skin. Microvasc. Res. 70, 198-204.

Chung, S., Furihata, M., Tamura, K., Uemura, M., Daigo, Y., Nasu, Y., Miki, T., Shuin, T., Fujioka, T., Nakamura, Y., 2009. Overexpressing PKIB in prostate cancer promotes its aggressiveness by linking between PKA and Akt pathways. Oncogene 28, 2849-2859.

Clayton, D., 2012. snpStats: SnpMatrix and XSnpMatrix classes and methods. 〈http:// www-gene.cimr.cam.ac.uk/clayton>.

Consonni, S.R., Werneck, C.C., Sobreira, D.R., Kühne, F., Moraes, S.G., Alvares, L.E., Joazeiro, P.P., 2012. Elastic fiber assembly in the adult mouse pubic symphysis during pregnancy and postpartum. Biol. Reprod. 86, 151 (151-110).

Corbet, N., Prayaga, K., Johnston, D., Burrow, H., 2007. Genetic variation in adaptive traits of cattle in North Australia. Proc. Assoc. Advmt. Anim. Breed. Genet 348-351.

Dennis, G., Sherman, B.T., Hosack, D.A., Yang, J., Gao, W., Lane, H.C., Lempicki, R.A., 2003. DAVID: database for annotation, visualization, and integrated discovery. Genome Biol. 4, R60.

Drujont, L., Lemoine, A., Moreau, A., Bienvenu, G., Lancien, M., Cens, T., Guillot, F., Bériou, G., Bouchet-Delbos, L., Fehling, H.J., 2016. ROR $\gamma \mathrm{t}+$ cells selectively express redundant cation channels linked to the Golgi apparatus. Sci. Rep. 6, 23682.

Fernando, R., Garrick, D., 2008. GenSel-User manual for a portfolio of genomic selection related analyses. 3. (Accessed 14 July 2017). 〈http://taurus.ansci.iastate.edu/ $\rangle$.

Fordyce, G., McGowan, M.R., Lisle, A., Muller, T., Allen, J., Duff, C., Holroyd, R.G., Corbet, N.J., Burns, B.M., 2014. Scrotal circumference of Australian beef bulls. Theriogenology 81, 805-812.

Fortuny, D., Balmaña, J., Graña, B., Torres, A., Cajal, T.Ry, Darder, E., Gadea, N., Velasco, A., López, C., Sanz, J., 2008. Opinion about reproductive decision making among individuals undergoing BRCA1/2 genetic testing in a multicentre Spanish cohort. Hum. Reprod. 24, 1000-1006.

Garrick, D.J., Taylor, J.F., Fernando, R.L., 2009. Deregressing estimated breeding values and weighting information for genomic regression analyses. Genet. Sel. Evol. 41, 1.

Gitton, Y., Dahmane, N., Baik, S., i Altaba, A.R., Neidhardt, L., Scholze, M., Herrmann, B.G., Kahlem, P., Benkahla, A., Schrinner, S., 2002. A gene expression map of human chromosome 21 orthologues in the mouse. Nature 420, 586-590.

Habier, D., Fernando, R.L., Kizilkaya, K., Garrick, D.J., 2011. Extension of the bayesian alphabet for genomic selection. BMC Bioinforma. 12, 186.

Hu, Z.-L., Fritz, E.R., Reecy, J.M., 2006. AnimalQTLdb: a livestock QTL database tool set for positional QTL information mining and beyond. Nucleic Acids Res. 35, D604-D609.

Kang, X., Liu, G., Liu, Y., Xu, Q., Zhang, M., Fang, M., 2013. Transcriptome profile at different physiological stages reveals potential mode for curly fleece in Chinese tan sheep. PloS ONE 8, e71763.

Kinsella, R.J., Kähäri, A., Haider, S., Zamora, J., Proctor, G., Spudich, G., Almeida-King, J., Staines, D., Derwent, P., Kerhornou, A., 2011. Ensembl BioMarts: a hub for data retrieval across taxonomic space. Database 2011.

Kizilkaya, K., Fernando, R.L., Garrick, D.J., 2010. Genomic prediction of simulated multibreed and purebred performance using observed fifty thousand single nucleotide polymorphism genotypes1. J. Anim. Sci. 88, 544-551.

Koury Filho, W., Jubileu, Jd.S., Eler, J., Ferraz, J., Pereira, E., Cardoso, E., 2003. Parâmetros genéticos para escore de umbigo e características de produção em bovinos da raça Nelore. Arq. Bras. Med. Vet. Zoot. 55, 594-598.

Levina, E., Ji, H., Chen, M., Baig, M., Oliver, D., Ohouo, P., Lim, C.-U., Schools, G., Carmack, S., Ding, Y., 2015. Identification of novel genes that regulate androgen receptor signaling and growth of androgen-deprived prostate cancer cells. Oncotarget 6, 13088.

Li, M., Tiirikka, T., Kantanen, J., 2014. A genome-wide scan study identifies a single nucleotide substitution in ASIP associated with white versus non-white coat-colour variation in sheep (Ovis aries). Heredity 112, 122-131.

McGowan, M., Bertram, J., Fordyce, G., Fitzpatrick, L., Miller, R., Jayawardhana, G., Doogan, V., De Faveri, J., Holroyd, R., 2002. Bull selection and use in northern Australia: 1. Physical traits. Anim. Reprod. Sci. 71, 25-37.

Mokry, F.B., Higa, R.H., de Alvarenga Mudadu, M., de Lima, A.O., Meirelles, S.L.C., da Silva, M.V.G.B., Cardoso, F.F., de Oliveira, M.M., Urbinati, I., Niciura, S.C.M., 2013 Genome-wide association study for backfat thickness in Canchim beef cattle using Random Forest approach. BMC Genet. 14, 47.

Monaco, G., van Dam, S., Ribeiro, J.L.C.N., Larbi, A., de Magalhães, J.P., 2015. A comparison of human and mouse gene co-expression networks reveals conservation and divergence at the tissue, pathway and disease levels. BMC Evol. Biol. 15, 259.

Nicolau, C., Silva, R., Mota, L., Veríssimo, C., 2004. Características da pele e do pelame em bovinos da raça Caracu. Arch. Zootec. 53, 25-34.

Nuño-Ayala, M., Guillen, N., Arnal, C., de Martino, A., García-de-Jalón, J.-A., Gascón, S. Osaba, L., Osada, J., Navarro, M.-A., 2012. Cystathionine $\beta$-synthase deficiency causes infertility by impairing decidualization and gene expression networks in uterus implantation sites. Physiol. Genom.

Onteru, S.K., Gorbach, D.M., Young, J.M., Garrick, D.J., Dekkers, J.C., Rothschild, M.F., 2013. Whole genome association studies of residual feed intake and related traits in the pig. PloS ONE 8, e61756.

Ortega, J., Daft, B., Assis, R., Kinde, H., Anthenill, L., Odani, J., Uzal, F.A., 2007. Infection of internal umbilical remnant in foals by Clostridium sordellii. Vet. Pathol. Online 44, 269-275.

Porto-Neto, L.R., Reverter, A., Prayaga, K.C., Chan, E.K., Johnston, D.J., Hawken, R.J., Fordyce, G., Garcia, J.F., Sonstegard, T.S., Bolormaa, S., 2014. The genetic architecture of climatic adaptation of tropical cattle. PloS One 9, e113284.

R Development Core Team, 2013. R: A Language and Environment for Statistical Computing. R Foundation for Statistical Computing, Vienna, Austria.

Rabelo, R.E., Vulcani, V.A.S., Cardoso, L.D., Campus Jataí, G., Tavares, H., Almeida, P., Roncatto, F., 2012. Aspectos anatômicos e sua relação com as enfermidades do prepúcio e pênis no touro. Rev. Eletri. Med. 9, 1-24.

Regitano, Ld.A., Coutinho, L., 2001. Biologia Molecular Aplicada à Produção Animal. Embrapa Informação Tecnológica, Brasília.

Santana, M.H., Utsunomiya, Y.T., Neves, H.H., Gomes, R.C., Garcia, J.F., Fukumasu, H., Silva, S.L., Junior, G.A.O., Alexandre, P.A., Leme, P.R., 2014. Genome-wide association analysis of feed intake and residual feed intake in Nellore cattle. BMC Genet. $15,1$.

Santiago, G., Siqueira, F., Cardoso, F., Regitano, L., Ventura, R., Sollero, B., Souza, M. Mokry, F., Ferreira, A., Torres, R., 2017. Genomewide association study for production and meat quality traits in Canchim beef cattle. J. Anim. Sci.

Sargolzaei, M., Chesnais, J.P., Schenkel, F.S., 2014. A new approach for efficient genotype imputation using information from relatives. BMC Genom. 15, 478.

Schurink, A., Wolc, A., Ducro, B.J., Frankena, K., Garrick, D.J., Dekkers, J.C., van Arendonk, J.A., 2012. Genome-wide association study of insect bite hypersensitivity in two horse populations in the Netherlands. Genet. Sel. Evol. 44, 31.

Sharov, A.A., Sharova, T.Y., Mardaryev, A.N., di Vignano, A.T., Atoyan, R., Weiner, L., Yang, S., Brissette, J.L., Dotto, G.P., Botchkarev, V.A., 2006. Bone morphogenetic protein signaling regulates the size of hair follicles and modulates the expression of cell cycle-associated genes. Proc. Natl. Acad. Sci. USA 103, 18166-18171.

Silva, R.G., La Scala Jr, N., Pocay, P.L.B., 2001. Transmissão de radiação ultravioleta através do pelame e da epiderme de bovinos1. Rev. Bras. Zootec. 30, 1939-1947.

Sollero, B., GULIAS-GOMES, C., Roso, V., Higa, R., YOKOO, M., Cardoso, L., Caetano, A., Cardoso, F., 2014. Goodness of fit comparisons among five bayesian models in genome-wide association of tick resistance in brazilian Hereford and Braford beef cattle. Embrapa Pecuária Sul-Artigo em anais de congresso (ALICE). In: World congress on genetics applied to livestock production, 10., 2014, Vancouver, British Columbia, Canada. Proceedings... Champaign: ASAS, 2014.

Tachibana, Y., Nakano, Y., Nagaoka, K., Kikuchi, M., Nambo, Y., Haneda, S., Matsui, M., Miyake, Y.-i., Imakawa, K., 2013. Expression of endometrial immune-related genes possibly functioning during early pregnancy in the mare. J. Reprod. Dev. 59, 85-91.

Tsai-Morris, C.-H., Koh, E., Sheng, Y., Maeda, Y., Gutti, R., Namiki, M., Dufau, M.L., 2007. Polymorphism of the GRTH/DDX25 gene in normal and infertile Japanese men: a 
missense mutation associated with loss of GRTH phosphorylation. Mol. Hum. Reprod. $13,887-892$.

Tsuma, V., Einarsson, S., Madej, A., Forsberg, M., Lundeheim, N., 1997. Plasma levels of progesterone and cortisol after ACTH administration in lactating primiparous sows. Acta Vet. Scand. 39, 71-76.

Tupy, O., Primavesi, O., Barbosa, P., 2006. Avaliação dos Impactos Econômicos, Sociais e Ambientais de Tecnologias da Embrapa Pecuária Sudeste. 1. Utilização de Touros da Raça Canchim em Cruzamento Terminal Com Fêmeas da Raça Nelore. Embrapa Pecuária Sudeste-Documentos (INFOTECA-E).
Utsunomiya, Y.T., Carmo, A.S., Neves, H.H., Carvalheiro, R., Matos, M.C., Zavarez, L.B., Ito, P.K., O'Brien, A.M.P., Sölkner, J., Porto-Neto, L.R., 2014. Genome-wide mapping of loci explaining variance in scrotal circumference in nellore cattle. PloS ONE 9 , e88561.

Windeyer, M., Leslie, K., Godden, S., Hodgins, D., Lissemore, K., LeBlanc, S., 2014.

Factors associated with morbidity, mortality, and growth of dairy heifer calves up to 3 months of age. Prev. Vet. Med. 113, 231-240.

Wood, H.M., Lee, U.J., Vurbic, D., Sabanegh, E., Ross, J.H., Li, T., Damaser, M.S., 2009. Sexual development and fertility of Loxl1 - /-male mice. J. Androl. 30, 452-459. 